\title{
Inherited haemoglobin variants in a South African population
}

\author{
A R BIRD*, P Ellis,$+ \mathrm{K}$ WOOD,$+ \mathrm{C}$ MATHEW \\ From * the Department of Haematology, Groote Schuur Hospital and University of Cape Town; the \\ Department of Paediatrics and Haematology, Red Cross War Memorial Children's Hospital and University of \\ Cape Town; and $\ddagger$ the MRC Research Unit for Molecular and Cellular Cardiology, University of Stellenbosch \\ Medical School, Tygerberg, South Africa.
}

SUMMARY We present the findings of a survey to determine the prevalence of inherited haemoglobin disorders in the Coloured (mixed ethnic origin) population of South Africa. A variety of haemoglobins was found. Of the structural variants, $\mathrm{Hb} \mathrm{E}$ and $\mathrm{Hb} \mathrm{S}$ were the most common, the former probably originating from South-East Asia and the latter from East Africa and possibly Madagascar. The $\alpha^{+}(-\alpha)$ thalassaemia haplotype is particularly common with an observed frequency of 0.023 . $\beta$ thalassaemia was rather less common, while hereditary persistence of fetal haemoglobin was found for the first time in this population group, occurring in two subjects.

The thalassaemia syndromes and other haemoglobin variants have been described in most of the racial groups in South Africa. In the Coloured population (mixed ethnic origin) two surveys have estimated a carrier rate for the heterozygous state for haemoglobin S (sickle cell trait, $\mathrm{Hb}$ AS) of $0.85 \%$ and $0.4 \%$ respectively. ${ }^{12}$ A survey of 627 children with microcytic anaemia yielded five cases of $\mathrm{Hb}$ AS $(0 \cdot 8 \%)$, including one patient doubly heterozygous for sickle cell trait and $\beta$ thalassaemia. ${ }^{3}$ The homozygous disease, as expected, is rare with only sporadic case reports. ${ }^{4-6}$ Carrier rates for the heterozygous state for $\mathrm{Hb} \mathrm{E}(\mathrm{Hb} \mathrm{AE})$ and $\mathrm{Hb} \mathrm{C}(\mathrm{Hb} \mathrm{AC})$ were estimated at $0.9 \%$ and $0.3 \%$ respectively for the Cape Malay Coloured population and as $1 \%$ and $0.3 \%$ for the non-Malay Coloured group. ${ }^{2}$ In the white population, the same survey gave the following frequency estimation: $\mathrm{Hb}$ AS $0.2 \%, \mathrm{Hb} \mathrm{AE} 0.2 \%$, and $\mathrm{Hb} \mathrm{AC}$ $0.4 \%$, but these figures seem rather high for a purely Caucasian population. Reports of homozygous $\mathrm{Hb} \mathrm{C}$ disease in a white family have been published,${ }^{67}$ but a report of sickle cell anaemia in this population group is difficult to substantiate. ${ }^{8}$ The rarity of the sickle cell gene among South African Blacks is well documented. ${ }^{910}$ Haemoglobin $\mathrm{S}$ has been described in a South African Indian population, ${ }^{11}$ including reports of the homozygous state, ${ }^{12} 13$ but we are

Received for publication 18 October 1985

Revised version accepted for publication 2 January 1986 not aware of any publications concerning the prevalence of other haemoglobin variants in this group. Several other haemoglobin variants have been reported in South Africa: $\mathrm{Hb} \mathrm{S} / \beta$ thalassaemia,${ }^{14} \mathrm{Hb}$ $\mathrm{E} / \boldsymbol{\beta}$ thalassaemia, ${ }^{15} \mathrm{Hb} \mathrm{M}$ Iwate and $\mathrm{Hb} \mathrm{M}$ Saskatoon, ${ }^{16}{ }^{17} \mathrm{Hb}$ J Cape Town,${ }^{18}$ and three cases of unstable haemoglobins. ${ }^{19-21}$ We have also identified $\mathrm{Hb} \mathrm{D}$ in two families.

There have been few studies of the incidence of the thalassaemias in South African populations. Bird et $a l^{3}$ studied a group of children with microcytic anaemia and found a $7 \cdot 2 \%$ prevalence of $\beta$ thalassaemia in this selected sample, but no estimation of the frequency of $\alpha$ thalassaemia was made. Mathew et $a^{22}$ studied the molecular basis of $\alpha$ thalassaemia in the Cape Coloured population and Rousseau and Mathew $^{23}$ analysed Hb Bart's in random cord blood samples in the same population group. Ramsay and Jenkins ${ }^{24}$ published figures for the prevalence of $\alpha$ thalassaemia in the Venda and San groups, while Piliszek ${ }^{25}$ performed a survey of $\mathrm{Hb}$ Bart's in the cord blood of Blacks in the Johannesburg area. We have documented $\mathrm{Hb} \mathrm{H}$ disease in several patients, although there have been no cases of Hb Bart's hydrops fetalis reported locally. One case of $\mathrm{Hb}$ Bart's syndrome has been described in a Chinese family in Johannesburg. ${ }^{26}$

Since estimation of $\mathrm{Hb}$ Bart's levels in neonates is probably not reliable as an index of the prevalence of 
$\alpha$ thalassaemia, ${ }^{27}$ we undertook a survey of haemoglobinopathies in donors to our local Blood Transfusion Service; $\alpha$ thalassaemia was screened for in suspect donors by DNA analysis.

\section{Materials and methods}

Between August 1981 and August 1983, Coloured donors from randomly chosen clinics of the Western Province Blood Transfusion Service in Cape Town were screened. The donor population was drawn from clinics at factories in the greater Cape Town area. The factories were selected only on the basis of size, with a preference for those with a large number of donors. All donors attending each clinic were studied irrespective of whether they failed the screening test.

A full blood count was performed on a Coulter Model S Plus II and electrophoresis of a freshly prepared haemolysate was performed on cellulose acetate at $\mathrm{pH} 8.9$ according to standard methods. ${ }^{28}$ Abnormal haemoglobins were further analysed by agar gel electrophoresis at $\mathrm{pH} 6 \cdot 0$, to distinguish $\mathrm{Hb}$ $\mathrm{E}$ from $\mathrm{Hb} \mathrm{C}$ and $\mathrm{Hb} \mathrm{S}$ from $\mathrm{Hb} \mathrm{D} .{ }^{29}$ In donors with a mean cell volume (MCV) of less than $80 \mathrm{fl}$, or a mean cell haemoglobin $(\mathrm{MCH})$ of less than $27 \mathrm{pg}$, or who had low haemoglobin values $(<13.5 \mathrm{~g} / \mathrm{dl}$ for males, $<12.5 \mathrm{~g} / \mathrm{dl}$ for females), further tests were performed as follows. $\mathrm{Hb} \mathrm{A}_{2}$ was assayed by a microchromatographic procedure using DEAE cellulose columns ${ }^{30}$ (Helena Laboratories), Hb F was measured using an alkali denaturation technique, ${ }^{31}$ and serum ferritin by a radioimmunometric method. ${ }^{32}$ In those donors with microcytosis or hypochromia or both, associated with normal ferritin, $\mathrm{Hb} \mathrm{A}_{2}$, and $\mathrm{Hb} F$ values, globin synthesis studies $^{33}$ and DNA analysis were performed. DNA was analysed by Southern blotting and hybridisation with an $\alpha$ globin complementary DNA probe and a $\zeta$ globin genomic probe, as previously reported. ${ }^{22} 23$

\section{Results}

A total of 1006 donors was screened, but 17 specimens were unsuitable for analysis and were therefore excluded, leaving a total of 989 . The results are outlined in tables 1 and 2. Of the 989 donors, there were 521 males and 469 females. Haemoglobins $\mathrm{E}$ and $\mathrm{S}$ were the commonest structural variants

TABLE 1 Structural haemoglobin variants.

\begin{tabular}{lllll}
\hline $\begin{array}{l}\text { Total } \\
\text { No }\end{array}$ & $H b A E$ & $H b A S$ & $H b A C$ & Other \\
\hline 989 & 10 & 10 & 1 & 0 \\
\hline
\end{tabular}

TABLE 2 Thalassaemias.

\begin{tabular}{|c|c|c|c|c|c|c|}
\hline \multirow{2}{*}{$\begin{array}{l}\text { Total } \\
\text { No }\end{array}$} & \multicolumn{4}{|c|}{$x$ thalassaemia } & \multirow[t]{2}{*}{$\beta$ thalassaemia } & \multirow[t]{2}{*}{$H P F H$} \\
\hline & $-\alpha / \alpha \alpha$ & $-\alpha /-\alpha$ & $--/ \alpha \alpha$ & $--/-\alpha$ & & \\
\hline 864 & 24 & 8 & 1 & 0 & 7 & 2 \\
\hline
\end{tabular}

detected, each with a prevalence of $1 \% \mathrm{Hb} \mathrm{C}$ trait was seen in only one donor.

There were 125 donors who were iron deficient (as $\vec{\omega}$ judged by serum ferritin values). Iron deficiency may depress the $\mathrm{Hb} \mathrm{\textrm {A } _ { 2 }}$ levels and produce hypochromia $\overline{3}$ and microcytosis which may obscure thalassaemic red cell indices. Since there is no association between + thalassaemia and iron deficiency, this group was it excluded in the assessment of the prevalence of the $\frac{\mathrm{N}}{\mathrm{G}}$ thalassaemias. A total of 45 donors had DNA analyses. Of these, 33 were documented as having $\alpha^{?}$ thalassaemia. Twenty-four were heterozygous for the $\vec{D}$ $\alpha^{+}(-\alpha /)$ determinant, eight were homozygous for을. this gene, and there was one donor heterozygous for the $\alpha^{\circ}(--/)$ haplotype. Globin synthesis studies $\varphi_{\infty}$ were undertaken in nine of the 12 subjects with. microcytic or hypochromic indices who had normalo DNA analyses to exclude cases of non-deletion $\alpha$ \& thalassaemia $\left(\alpha \alpha^{\mathbf{T}}\right)$, but none was detected. $\alpha / \beta$ globin $\frac{}{0}$ synthesis ratios were also determined in the cases of $\alpha$ thalassaemia documented by DNA analysis and $\stackrel{\alpha}{\square}$ these are shown in the figure. In the donor with the $\underset{\vec{P}}{\overrightarrow{0}}$ $--/$ determinant and in the donors homozygous for $\frac{0}{3}$

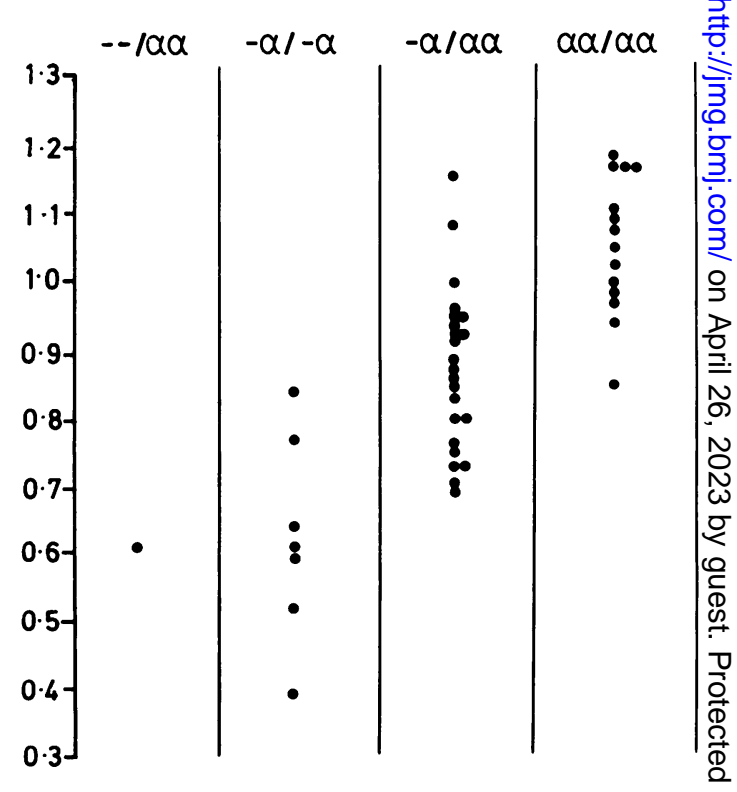

FIGURE $\alpha / \beta$ globin biosynthetic ratios in the $\alpha$ thalassaemias? 
the $-\alpha /$ haplotype, there was no overlap with a group of 13 normal controls. There was, however, considerable overlap between those heterozygous for the $-\alpha$ / haplotype and normal subjects.

The data from table 1 have been used to calculate the frequencies of the different $\alpha$ thalassaemia determinants. The observed frequency of the $-\alpha /$ haplotype is 0.023 , while that of the $--/$ determinant is less than 0.001 . Based on the HardyWeinberg equation the predicted number of $-\alpha / \alpha \alpha$ genotypes is $0 \cdot 173$.

$\beta$ thalassaemia was far less frequent than $\alpha$ thalassaemia with only seven cases detected, a prevalence of $0.08 \%$. Two donors with hereditary persistence of fetal haemoglobin were also found.

We were able to obtain some family history in 38 donors with haemoglobin variants. In five there was evidence of South-East Asian ancestry (based on religious beliefs) and in two there was a Chinese background, including the single donor with the - - / determinant. The remainder were of diverse origins, although the majority appeared to be at least third generation South Africans.

\section{Discussion}

These studies confirm that there is a variety of haemoglobins in the Cape Coloured population. Of the structural variants, $\mathrm{Hb} \mathrm{E}$ and $\mathrm{Hb} \mathrm{S}$ were the most common. $\mathrm{Hb} \mathrm{E}$ was first described in Thailand and is known to be common in South-East Asia. ${ }^{34}$ The greatest incidence is among Burmese, Thais, and the people of North-East Malaysia. $\mathrm{Hb} \mathrm{E}$ is also common in some Indonesian communities especially on the islands of Sumba, Sumbawa, and Timor ${ }^{35}$ Many South-East Asians who were brought to the Cape during the early years of the settlement came from these islands. ${ }^{2}$ Curiously only four of the 10 carriers of $\mathrm{Hb} \mathrm{E}$ had microcytic, hypochromic red cells. Other studies ${ }^{36}{ }^{37}$ have shown a more striking association, although we have documented $\mathrm{Hb} \mathrm{E}$ carriers with normal indices. ${ }^{38}$

The finding of a $1 \%$ prevalence of $\mathrm{Hb} \mathrm{S}$ in the Coloured population was slightly surprising, although the earliest survey in 1953, using Itano's sickling test, indicated a prevalence of $0.85 \%$. Presumably the origin of the sickle gene is Madagascar or India, whence slaves were imported by the Dutch East India Company in the 17th and 18 th centuries. DNA studies tend to substantiate this, since the sickle gene in the local population has been shown to be associated with the $7.6 \mathrm{~kb}$ fragment using HpaI (C G P Mathew, unpublished data).

Since patients with persistent red cell hypochromia or microcytosis or both are often referred to us, we were not surprised to find thalassaemia trait relatively commonly. $\alpha$ thalassaemia is the most common, occurring in $3.8 \%$ of the surveyed sample. The major ethnic influences of the Coloured people are: (1) Southern African peoples, including indigenous Khoikhoi and slaves imported from Madagascar and East Africa during the 17th and 18th centuries; (2) Asians, who were slaves and political exiles imported by the Dutch East India Company, particularly from Indonesia and India; and (3) Western Europe, particularly the Netherlands. $\alpha$ thalassaemia is very uncommon in Western Europe but is well documented in Indonesia. ${ }^{39}{ }^{40}$ Since the Khoikhoi have been assimilated into the Cape Coloured population, the main sources appear to be India, East Africa, and Madagascar, although Ramsay and Jenkins have studied a group of San ('Bushmen') from the Kalahari region of Namibia and found the $-\alpha /$ determinant to occur at a frequency of $0.06 .^{24}$ They postulated that the $-\alpha /$ determinant has a significant protective effect against malaria and that it may, in addition, have a selective advantage against other, as yet undetermined, environmental agents. It is therefore possible that the original Khoikhoi tribes also had a significant incidence of the $-\alpha /$ determinant and that was a further source of the pool of $-\alpha$ / haplotypes in the Coloured population. The single $\alpha^{\circ}(--/)$ haplotype detected had the same $\zeta$ globin restriction fragment pattern as the South-East Asian $\alpha^{\circ}(--$ SEA $){ }^{41}$

The frequency of carriers calculated from the Hardy-Weinberg equation $(0 \cdot 173)$ contrasts with the observed heterozygote frequency of 0.027 , and similarly the observed frequency of the $-\alpha$ / haplotype of 0.023 against the calculated result of 0.09 . This confirms the impression that many persons with the $-\alpha / \alpha \alpha$ genotype are not detected by screening persons with red cell hypochromia or microcytosis or both. Based on a comparison of our results with those of Rousseau and Mathew ${ }^{23}$ such screening is no more efficient in identifying $\alpha$ thalassaemia carriers than surveys of $\mathrm{Hb}$ Bart's in neonates. These authors based their calculations of $\alpha$ thalassaemia gene frequency in the same population group on follow up DNA analysis of neonates with $\mathrm{Hb}$ Bart's in cord blood samples. They found an observed heterozygote frequency for the $-\alpha$ / determinant of 0.02 , with a calculated frequency of 0.165 . The expected frequency of the $-\alpha /$ haplotype was 0.091 with an observed frequency of 0.018 . These figures are very similar to those of our study. Despite these limitations, such surveys should give a reasonably accurate figure, since all persons with the genotype $-\alpha /-\alpha$ are probably detected and the estimated frequency of the $-\alpha /$ carriers is calculated in the Hardy-Weinberg equation from the number of $-\alpha /$ homozygotes. Ultimately, confirmation of this would 
come from large scale population surveys using DNA analysis alone, but this would be extremely costly.

We were a little surprised to find only seven donors with $\beta$ thalassaemia trait since we have a large number of patients on record with this condition. This, however, may simply reflect the relatively easier laboratory diagnosis compared to $\alpha$ thalassaemia. The origin of the gene is presumably South-East Asia where it is well documented and is also widespread among the Indonesian islands. ${ }^{39}$ An African origin is unlikely since there are only sporadic reports from East and Central Africa.

The discovery of two donors with HPFH was interesting, since the condition has not been reported in this population group before, and there is only one previous report from South Africa, in a Black family from the Venda tribe. ${ }^{42}$ The features are suggestive of the Negro variety of HPFH, which has been reported sporadically in many races.

We gratefully acknowledge the excellent cooperation of the staff of the Western Province Blood Transfusion Service, in particular Mrs Sweeney, and the additional technical assistance from the staff of the Haematology Laboratory at the Children's Hospital. We thank Ms D Hoffa for typing the manuscript. This work was supported by grants from the Medical Research Council of South Africa, the Mobil Research Foundation, the University of Cape Town, and the Harry Crossley Foundation.

\section{References}

1 Esrachowitz SR, Friedlander S, Radloff G, Saunders S. The sickle trait in Cape Coloured persons. $S$ Afr Med J 1952;26: 239-40.

2 Botha MC, Van Zyl LT. Abnormal haemoglobins in Cape Town. S Afr Med J 1966;40:753-6.

3 Bird AR, Karabus CD, Hartley PS. Microcytic anaemia and haemoglobinopathy in Cape Town children. $S$ Afr Med J 1982;62:429-30

4 Wasserman HP. Sekelselanemie 'n studie van 'n Kleurlingfamilie. S Afr Med J 1958;32:953-6.

5 Anstey L, Elstein M. Sickle-cell trait: a family study and a report of three further cases of sickle-cell disease. $S$ Afr Med J 1960;34:282-3.

6 Botha MC, Pritchard J, Van Zyl L. Homozygous abnormal haemoglobins in Cape Town. $S$ Afr Med J 1967;41:66-75.

7 Lewis SM, Anderson CG, Baskind E. Homozygous haemoglobin-C disease in a white family with special reference to blood autolysis studies. Br J Haematol 1957;3:68-76.

8 Altman A. Sickle cell anaemia in a South African-born European. Clin Proc 1945;4:1-10.

9 Griffiths SV. The distribution of the sickle cell trait in Africa. $S$ Afr Med J 1954;19:56-7.

10 Bernstein RE. Sickle haemoglobin in South Africa. S Afr Med J 1969;43:1455-6.

11 Reddy MV, Ward FA. The sickle cell phenomenon in South Africa. $S$ Afr Med J 1969;43:1217-9.

12 Naude EE, Neame PB. Sickle cell trait in the Natal Indian. $S A f r$ Med J 1961;35:1026.
13 Segal F, Grusin H, Cassel R. Sickle-cell anaemia in a young Coloured adult male. $S$ Afr Med J 1956;30:63-5.

14 Nathanson SD, Dunn JA, Bradlow BA. Sickle cell thalassaemif in Johannesburg: a case discussion and family study. $S$ Afr Mead 1968;42:749-53.

15 Brain P, Budtz-Olsen OE. Thalassaemia-haemoglobin 霄: disease in a Cape Coloured family. S Afr Med J 1958;32:553-4

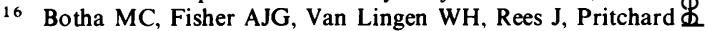
Haemoglobin $\mathbf{M}$ in a Cape Coloured family. $S$ Afr Med 1967;41:263-7.

17 Bernstein RE. Whither medical genetics in South Africa? $\vec{\Phi}$ perspective of some inborn metabolic defects in man. Med Práa 1965;11:625-35.

18 Botha MC, Beale D, Isaacs WA, Lehmann H. Haemoglobind Cape Town $-\beta_{2}{ }^{92}$ arginine-glutamine $\beta_{2}$. Nature 1966;21 792-5.

19 Grové SS, Jenkins T, Kamuzora HL, Lehmann H. Congenitiab Heinz body haemolytic anaemia due to haemoglobin Perth in. Nama child. Acta Haematol (Basel) 1977;57:143-51.

20 Perlman MM, Wiltshire B, Stevens K, Carrell R, Lehmann A Haemoglobin Leiden in a South African negro. $S$ Afr Med $\mathrm{Cr}^{\prime}$

21 Bird AR, Karabus CD, Hartley PS, Lehmann H, Conway Haemoglobin Köln in Cape Town. Submitted for publication.

22 Mathew CGP, Rousseau J, Rees JS, Hartley EH. The moleculof basis of alpha thalassaemia in a South African population. Brב్. Haematol 1983;55:103-11.

23 Rousseau J, Mathew CGP. The incidence of Hb Barts and alph $\overrightarrow{5}$ thalassaemia genotypes in a South African population. Acța Haematol (Basel) 1985;73:159-62.

24 Ramsay M, Jenkins T. $\alpha$-thalassaemia trait in Africa: the oldeg malaria protective trait? Lancet $1984 ; \mathbf{i i}: 410$.

25 Piliszek TS. Hb Barts and its significance in the South Africen negro. Acta Haematol (Basel) 1979;61:55-8.

26 Sevitz H, Klein R, Sonnendecker EWW, Lubbe FJ, Merrell DAR Rothberg AD. Non-immunological hydrops fetalis: report of cases and a review. $S$ Afr Med J 1982;62:815-9.

27 Higgs DR, Lamn J, Aldridge BE, et al. Inadequacy haemoglobin Barts as an indicator of alpha thalassaemia. $B r \pm$ Haematol 1982;51:177-8.

28 Dacie JV, Lewis SM. Practical haematology. 6th ed. Edinburgh: London: Churchill-Livingstone, 1984.

29 Robinson AR, Robinson M, Harrison AP, Zuelzer WW. A ne technique for differentiation of haemoglobin E. J Lab Clin M 1957:50:745-52.

30 Huisman TJ, Schroeder WA, Brodie AN, Mayson SM, Jakway.d. Microchromatography of hemoglobins III: a simplified prQ cedure for the determination of hemoglobin $\mathrm{A}_{2} . \mathrm{J} \mathrm{Lab} C$ Med 1975;86:700-2.

31 Pembrey ME, McWade P. Weatherall DJ. Reliable routinc estimation of small amounts of foetal haemoglobin by alkitis denaturation. J Clin Pathol 1972;25:738-40.

32 Dempster WS, Steyn FL, Knight GJ, De V Heese Immunoradiometric assay of serum ferritin as a practiọi method for evaluating iron stores in infants and children. $M$ \& $d$ Lab Sci 1977;34:337-41.

33 Weatherall DJ, Clegg JB. The thalassaemia syndromes. Oxford Blackwell Scientific Publications, 1981.

34 Lehmann H, Huntsman RG. Man's haemoglobins. Amsterdam. North Holland, 1974.

35 Eng LJ. Pathological haemoglobins in Indonesia. In: Jonx JHP, Delafresnay JF, eds. Abnormal haemoglobins: a symposiumt Oxford; Blackwell Scientific Publications, 1959.

36 Fairbanks VF, Gilchrist GS, Brimhall B, Jereb JJ, Goldston E $\overline{6}$ Hemoglobin E trait re-examined: a cause of microcytosis and erythrocytosis. Blood 1979;53:109-15.

37 Traeger J, Wood WG, Clegg JB, Weatherall DJ, Wasi \& Defective synthesis of $\mathrm{Hb} \mathrm{E}$ is due to reduced levels $\beta^{E}$ mRNA. Nature 1980;288:497-9. 
38 Bird AR, Wood K, Leisegang F, et al. Haemoglobin E variants: a clinical, haematological and biosynthetic study of 4 South African families. Acta Haematol (Basel) 1984;72:135-7.

39 Lie-Injo LE. Haemoglobin of newborn infants in Indonesia. Nature 1959:183:1125-6.

40 Lie-Injo LE. Pathological haemoglobins in Indonesia. In: Jonxis JHP, Delafresnaye JF, eds. Abnormal haemoglobins: a symposium. Oxford: Blackwell Scientific Publications, 1959.

41 Higgs DR, Pressley L, Aldridge B, et al. Genetic and molecular diversity in non-deletion $\mathrm{HbH}$ disease. Proc Natl Acad Sci USA 1981;78:5833-7.

42 Jenkins T, Stevens K. Hereditary persistence of foetal haemoglobin in a South African family. S Afr Med J 1970;44:111-4.

Correspondence and requests for reprints to $\operatorname{Dr} \mathbf{A} \mathbf{R}$ Bird, Department of Haematology, Groote Schuur Hospital, Observatory, Cape 7925, South Africa. 